\title{
PENGHORMATAN HAK ASASI MANUSIA BAGI PENGHAYAT KEPERCAYAAN DI KOTA BANDUNG
}

\author{
Oki Wahju Budijanto \\ Badan Penelitian dan Pengembangan Hukum dan HAM \\ Kementerian Hukum dan HAM RI \\ JI. H.R. Rasuna Said Kav. 4-5 Kuningan Jakarta Selatan 12940 \\ e-mail : oki_olive@yahoo.com
}

Tulisan Diterima: 30-03-2016 Direvisi: 19-04-2016 Disetujui: 14-07-2016

\begin{abstract}
Abstrak
Penghayat Kepercayaan masih mengalami diskriminasi, khususnya dalam penghormatan hakhak sipilnya. Hal ini berakar dari "perbedaan" yang lahir dari pengakuan negara atas agama dan perlakuan berbeda kepada "agama" dan "kepercayaan". Pada Pemerintahan Joko Widodo-Jusuf Kalla salah satu agenda prioritas adalah memprioritaskan perlindungan terhadap anak, perempuan dan kelompok masyarakat termajinalkan, serta penghormatan HAM dan penyelesaian secara berkeadilan terhadap kasus-kasus pelanggaran HAM pada masa lalu menjadi momentum tepat untuk penegakan HAMnya. Pertannyaannya, implementasi penghormatan Hak Asasi Manusia bagi penghayat kepercayaan di Kota Bandung. Tulisan yang didasarkan pada penelitian bersifat deskriptif analisis dengan pendekatan yuridis normatif pada tataran implementasi (khususnya Kota Bandung), para penghayat kepercayaan tidak mengalami kendala dalam memperoleh layanan kependudukan dan catatan sipil. Namun demikian masih terdapat penolakan masyarakat umum terhadap pemakaman bagi para penghayat kepercayaan di tempat pemakaman umum. Penolakan ini tentu bertentangan dengan Pasal 8 ayat (2) Peraturan Bersama Menteri Dalam Negeri dan Menteri Kebudayaan dan Pariwisata Nomor 43 Tahun 2009 dan Nomor 41 Tahun 2009 tentang Pedoman Pelayanan Kepada Penghayat Kepercayaan Kepada Tuhan Yang Maha Esa, maka pemerintah daerah menyediakan pemakaman umum.
\end{abstract}

Kata Kunci: Penghormatan HAM, Hak-Hak Sipil, Penghayat Kepercayaan

\begin{abstract}
Belief adherent still experience discrimination, expecialy respect of their civil rights. it is rooted in the "difference" is born from the recognition of the state of religion and different treatment to "religion" and "belief". In Government Joko Widodo-Jusuf Kalla which one of the priority agenda is to prioritize the protection of children, women and marginalized groups of society, as well as respect for human rights and equitable settlement of the cases of human rights violations in the past an appropriate moment to better provide the respect of human rights. This paper based of research which is descriptive analysis with normative juridical approach in terms of implementation (particularly the city of Bandung), the seeker of confidence not having problems in obtaining settlement services and civil records. However, there is still a general public rejection of the funeral for the seeker of confidence in the public cemetery. This rejection against to Article 8 (2) Joint Regulation of the Minister of Home Affairs and Minister of Culture and Tourism No. 43 of 2009 and No. 41 of 2009 on Guidelines for Care To Belief adherent in God Almighty, the local government provides the public cemetery. Keywords: Respect of Human Rights, Civil Rights, Belief Adherent
\end{abstract}




\section{PENDAHULUAN}

\section{Latar Belakang}

Amanat amandemen kedua UndangUndang Dasar Negara Republik Indonesia Tahun 1945, khususnya Pasal 28E ayat (1) dan ayat (2) mencerminkan nilai dasar Ketuhanan Yang Maha Esa dalam bentuk yang lebih rinci yaitu kebebasan memeluk agama dan menjalankan ibadah menurut agama dan kepercayaannya masing-masing. Tidak hanya itu, hak kebebasan beragama/berkeyakinan juga termaktub di dalam Pasal 29 ayat (1) UUD 1945 yang menyatakan bahwa "Negara berdasar atas Ketuhanan Yang Maha Esa". Ayat selanjutnya menyebutkan bahwa "Negara menjamin kemerdekaan tiap-tiap penduduk untuk memeluk agamanya masingmasing dan untuk beribadat menurut agamanya dan kepercayaannya itu". Konsekuensi adanya jaminan di dalam konstitusi, menjadikan hak setiap warga Negara untuk menjalankan ajaran agama, keyakinan maupun ritual peribadatan telah menjadi hak konstitusional.

Negara telah menjamin hak berkepercayaan, tetapi nyatanya berbagai pelanggaran HAM kerapkali terjadi pada penghayat kepercayaan. Padahal di era reformasi seperti ini, dapat menjadi momentum yang dapat memupus segala bentuk aturan diskriminatif. Pada masa ini kita mengenal Undang-Undang Nomor 23 Tahun 2006 tentang Administrasi Kependudukan, yang telah disahkan pada 8 Desember 2006. Aturan ini dipandang sebagai langkah terobosan untuk mengatasi masalah diskriminasi di Indonesia. Harapan itu setidaknya termaktub dalam dua catatan berikut, yaitu: Pertama, dalam bagian penjelasan undang-undang ini secara tegas mengakui dan menyadari adanya masalah diskriminasi yang telah dan tengah berlangsung bagi warga negara. Pada paragraf keempat bagian umum dalam penjelasan disebutkan:

"Dalam pemenuhan hak Penduduk, terutama di bidang Pencatatan Sipil, masih ditemukan penggolongan Penduduk yang didasarkan pada perlakuan diskriminatif yang membeda-bedakan suku, keturunan, dan agama sebagaimana diatur dalam berbagai peraturan produk kolonial Belanda. Penggolongan Penduduk dan pelayanan diskriminatif yang demikian itu tidak sesuai dengan Pancasila dan Undang-Undang Dasar Negara Republik Indonesia Tahun 1945. Kondisi tersebut mengakibatkan pengadministrasian kependudukan mengalami kendala yang mendasar sebab sumber data kependudukan belum terkoordinasi dan terintegrasi, serta terbatasnya cakupan pelaporan yang belum terwujud dalam suatu sistem administrasi kependudukan yang utuh dan optimal".

Kedua, berawal dari pengakuan atas problem diskriminasi di bidang pencatatan sipil tersebut, undang-undang ini menawarkan paradigma baru dalam sistem administrasi kependudukan dimana sistem tersebut dimaksudkan bisa menjamin pemenuhan hak-hak administratif, seperti pelayanan publik serta perlindungan yang berkenaan dengan dokumen kependudukan, tanpa adanya perlakuan yang diskriminatif.

Namun, dalam perjalanan kehidupan berbangsa, khususnya pasca reformasi telah terjadi problem kebangsaan yang memprihatinkan, yaitu maraknya aksi anarkisme massal yang berbasis pada isu kesukuan, keagamaan-keyakinan, maupun rasisme. Dalam kasus pelanggaran kebebasan beragama dan berkeyakinan, masyarakat sedang mengalami gejala intoleransi dalam kehidupan keagamaan, misalkan dalam bentuk diskriminasi pelayanan terhadap para penghayat kepercayaan terhadap Tuhan (YME).

Serangkaian tindakan intoleran dan diskriminasi menunjukkan, bahwa gambaran tentang persatuan dan kesatuan bangsa telah mengalami degradasi. Menurut Mahfud MD, pergeseran rezim otoritarian menuju demokrasi jelas menjadi kabar sedap bagi kebebasan beragama, berkeyakinan, berekspresi dan berasosiasi. Namun, sejauh ini selalu saja terjadi masalah dalam implementasinya. Bahkan, ketika pemerintahan sudah terbentuk melalui mekanisme demokratis, ternyata belum berdaya mengurangi intensitas masalah kebebasan beragama. Indonesia divonis sebagai pelaku diskriminasi dalam beragama dan berkeyakinan, khususnya terhadap agama minoritas maupun kelompok penghayat serta masyarakat adat yang notabene termarginalkan'1.

1 Mahfud MD, Kebebasan Beragama Dalam Perspektif Konstitusi, Makalah yang disampaikan dalam 
Berdasarkan data Kementerian Kebudayaan dan Pariwisata, pada tahun 2009 ada 245 organisasi penghayat di tingkat pusat dan 954 organisasi di 25 provinsi di Indonesia, dengan jumlah pengikut sekitar 10 juta orang. Namun data tersebut pada tahun 2013 mengalami penurunan, berdasarkan data dari Direktorat Pembinaan Kepercayaan terhadap Tuhan Yang Maha Esa dan Tradisi, Kementerian Pendidikan dan Kebudayaan terdapat 237 organisasi penghayat di tingkat pusat. Hal ini dapat didasari karena, para penghayat kepercayaan telah hadir jauh sebelum Indonesia terbentuk, bahkan sebelum datangnya enam agama di Indonesia. Sebenarnya, pasca reformasi ada upaya hukum untuk melindungi hak-hak penghayat kepercayaan, melalui Undang-Undang Nomor 24 Tahun 2013 tentang Perubahan Atas Undang-Undang Nomor 23 Tahun 2006 tentang Administrasi dan Kependudukan (Adminduk), Peraturan Pemerintah Nomor 37 Tahun 2007 tentang PelaksanaanUU No. 23 Tahun2006, serta Peraturan Bersama Menteri Dalam Negeri dan Menteri Kebudayaan dan Pariwisata Nomor 43 dan 41 Tahun 2009 tentang Pedoman Pelayanan kepada Penghayat Kepercayaan Terhadap Tuhan YME. Namun, praktik diskriminasi masih terus berlangsung.

Kebijakan Negara atas "agama" dan "kepercayaan" dapat menimbulkan praktik diskriminasi. Hal ini didasarkan kepada UU No.1/PNPS/1965 tentang Pencegahan Penyalahgunaan dan/atau Penodaan Agama. Negara melakukan diskriminasi dalam bentuk favoritism dengan memberikan pengakuan dan perlindungan terhadap enam agama; Islam, Katolik, Kristen, Budha, Hindu dan Konghucu. Sedangkan penghayat kepercayaan terhadap Tuhan YME tidak mendapatkan pengakuan dan perlindungan, karena dinilai "tidak beragama". ${ }^{2}$ Karena tidak masuk dalam enam agama resmi, para penghayat kepercayaan yang jumlahnya

Konferensi Tokoh Agama ICRP: Meneguhkan Kebebasan Beragama di Indonesia, Menuntut Komitmen Presiden dan Wakil Presiden Terpilih, yang diselenggarakan oleh Indonesian Conference on Religion and Peace (ICRP) pada Senin, 5 Oktober 2009 di Ruang Vanda II Wisma Serbaguna, Jakarta. h. 1

2 Siti Aminah, Diskriminasi Pendidikan Agama di Perguruan Tinggi Umum, Mitra Hukum, ILRC, Jakarta, 2010, h. 2 jutaan, tidak dapat diproses melalui sistem e-KTP. Padahal KTP adalah tanda kependudukan yang harus diberikan kepada seluruh warga negara. Kelompok yang tidak dapat KTP itu antara lain Kaharingan di Kalimantan, Sunda Wiwitan di Jawa Barat dan Banten, serta Parmalim di Sumatera Utara ${ }^{3}$.

Provinsi Jawa Baratmerupakan wilayah yang banyak terjadi peristiwa-peristiwa pelanggaran Kebebasan Beragama dan Berkeyakinan (KBB), intoleransi dan diskriminasi baik yang melibatkan aktor negara maupun non Negara. Pada tahun 2014 saja disebutkan terjadinya 55 peristiwa ${ }^{4}$. Kasus pelanggaran kebebasan beragama dan berkeyakinan yang terjadi di Provinsi Jawa Barat yaitu penyegelan, pelarangan dan penutupan gereja diKabupaten Cianjur, KabupatenBandung, Kota Bandung dan Kabupaten Sumedang. ${ }^{5}$

\section{Rumusan Masalah}

Berdasarkan latar belakang permasalahan yang ada, maka dapat dirumuskan permasalahan sebagai berikut: bagaimana implementasi penghormatan Hak Asasi Manusia bagi penghayat kepercayaan di Kota Bandung.

\section{Tujuan Penelitian}

Tujuan penelitian ini diharapkan dapat menggambarkan tentang implementasi penghormatan Hak Asasi Manusia bagi penghayat kepercayaan di Kota Bandung.

\section{Metodologi Penelitian}

Dalam mencapai tujuan di atas, penelitian ini menggunakan metode pengumpulan data primer dan sekunder. Adapun data primer diperoleh secara langsung dari informan melalui wawancara yang dipandu dengan pedoman wawancara yang berisikan rangkaian pertanyaan mengenai suatu permasalahan yang akan diteliti. Informan pada penelitian ini, dikumpulkan dengan menggunakan teknik purposive accidental sampling. Sedangkan data sekunder berupa bahan hukum primer yaitu norma dasar, peraturan perundang-undangan,

3 http://www.jurnalparlemen.com/view/3106/penganutkepercayaan-tak-bisa-miliki-e-ktp-pemerintah-dinilaidiskriminatif.html.

4 The Wahid Institute "Laporan Akhir Tahun Kebebasan Beragama/Berkeyakinan Dan Intoleransi 2014"

5 http://icrp-online.org/2015/07/08/komnasham-kasuskebebasan-beragama-yang-lama-belum-tuntas/.html. 
bahan hukum yang dikodifikasikan, yurisprudensi yang kemudian dianalisis dengan menggunakan pendekatan yuridis normatif dan deskriptif analisis, bahan hukum sekunder (UndangUndang Dasar Negara Republik Indonesia Tahun 1945; Undang-Undang Nomor 1/PNPS/1965 tentang Pencegahan Penyalahgunaan dan/atau Penodaan Agama; Undang-Undang Nomor 23 Tahun 2006 tentang Administrasi Kependudukan; Undang-Undang Nomor 24 Tahun 2013 tentang Perubahan Atas Undang-Undang Nomor 23 Tahun 2006 tentang Administrasi dan Kependudukan; Peraturan Pemerintah Nomor 37 Tahun 2007 tentang Pelaksanaan UU No. 23 Tahun 2006; Peraturan Bersama Menteri Dalam Negeri dan Menteri Kebudayaan dan Pariwisata Nomor 43 dan 41 Tahun 2009 tentang Pedoman Pelayanan kepada Penghayat Kepercayaan. Terhadap Tuhan YME) sedangkan bahan hukum tersier diperoleh dari internet.

\section{PEMBAHASAN}

\section{Agama dan Kepercayaan Dalam Perspektif HAM}

Tanggal 28 Oktober 2005, pemerintah Indonesia mengesahkan ICESCR (International Covenant on Economic, Social, and Culture Right) menjadi UU Nomor 11 Tahun 2005 dan ICCPR (International Covenant on Civil and Political Right) menjadi UU Nomor 12 Tahun 2005. Ratifikasi tersebut menimbulkan konsekuensi terhadap pelaksanaan hak asasi manusia, karena Indonesia telah mengikatkan diri secara hukum. Artinya Pemerintah Indonesia memiliki kewajiban untuk mengadopsi kovenan kedalam bentuk undang-undang, selain itu juga memiliki kewajiban untuk menghormati, melindungi dan memenuhi HAM serta membuat laporan yang bertalian dengan penyesuaian hukum, langkah, kebijakan dan tindakan yang dilakukan.

Negara dalam hal ini pemerintah memiliki tanggung jawab untuk mewujudkan pemenuhan Hak Asasi Manusia dalam 3 (tiga) bentuk:
a. Penghormatan (to respect);
b. Perlindungan (to protect); dan
c. Pemenuhan (to fullfil).

Sebagai pemangku kewajiban, pemerintah juga dituntut untuk melakukan upaya-upaya pencegahan agar pelanggaran HAM melalui tindakan pembiaran (by ommision) tidak berlanjut, sebagai contoh peraturan daerah tentang perlindungan masyarakat adat.

Ada tiga prinsip utama dalam pandangan normatif HAM, yaitu berlaku secara universal, bersifat non-diskriminasi dan imparsial. Prinsip keuniversalan ini dimaksudkan agar gagasan dan norma-norma HAM telah diakui dan diharapkan dapat diberlakukan secara universal atau internasional. Prinsip ini didasarkan atas keyakinan bahwa umat manusia berada dimanamana, disetiap bagian dunia baik di pusatpusat kota maupun di pelosok-pelosok bumi yang terpencil. Berdasar hal itu HAM tidak bisa didasarkan secara partikular yang hanya bersifat kedaerahan dan diakui secara lokal.

Prinsip kedua dalam norma HAM adalah sifatnya yang non-diskriminasi. Prinsip ini bersumber dari pandangan bahwa semua manusia setara (all human being are equal). Setiap orang harus diperlakukan setara. Seseorang tidak boleh dibeda-bedakan antara satu dengan yang lainnya. Hal ini tidak bisa dipandang sebagai suatu hal yang negatif, melainkan harus dipandang sebagai kekayaan umat manusia. Karena manusia berasal dari keanekaragaman warna kulit seperti kulit putih, hitam, kuning dan lainnya. Keanekaragaman agama juga merupakan sesuatu hal yang mendapat tempat dalam sifat non-diskriminasi ini. Pembatasan seseorang dalam beragama merupakan sebuah pelanggaran HAM. Istilah diskriminasi tidak didefinisikan dalam Kovenan Internasional Hak Sipil dan Hak Politik (International Covenant on Civil and Political Rights/ICCPR), termasuk di dalamnya prinsip non diskriminasi. Namun, Komite Hak Asasi Manusia (The Human Rights Committee), melalui Komentar Umum Nomor 18 (General Comment) pada 1989, menekankan bahwa prinsip "non diskriminasi" semestinya ditampakan dalam tataran implementasi. Kesejajaran di muka hukum dan kesamaan perlindungan hukum tanpa diskriminasi, menjadi basis dan prinsip umum bagi upaya perlindungan HAM. ${ }^{6}$

Prinsip ketiga ialah imparsialitas. Maksud dari prinsip ini penyelesaian sengketa tidak

6 Rachel Hodgkin and Peter Newell, Implementation Handbook for the Convention on the Rights of the Child, UNICEF, New York, 1998, h. 21 
memihak pada suatu pihak atau golongan tertentu dalam masyarakat. Umat manusia mempunyai beragam latar belakang sosial maupun latar belakang kultur yang berbeda antara satu dengan yang lain hal ini merupakan sebuah keniscayaan. Prinsip imparsial ini dimaksudkan agar hukum tidak memihak pada suatu golongan.

Tujuan pembentukan negara adalah untuk melindungi hak warga negara dan memenuhi kepentingan seluruh rakyatnya. Dalam konteks ke-Indonesiaan, salah satu tujuan nasional adalah melindungi segenap bangsa Indonesia, tentu saja tanpa diskriminasi baik berdasarkan suku, bahasa, maupun agama. Oleh karena itu, menjadi salah satu tugas negara untuk melindungi hak kebebasan setiap orang dalam beragama dan beribadat. Dengan demikian, hak beragama merupakan salah satu hak yang tidak dapat dikurangi dalam keadaan apapun. Menurut Konstitusi Indonesia, hak beragama merupakan hak yang tidak dapat dikurangi (non-derograble rights).

Di dalam studi agama, kata kepercayaan (belief) biasanya selalu bersanding dengan kata agama (religion), sehingga frasa religion and belief atau religion or belief kerapkali ditemukan dalam referensi atau dokumen hak asasi manusia di barat. Dalam The World University Encyclopedia $^{7}$ pengertian religion dijelaskan sebagai sebuah terma yang menunjukkan hubungan antara manusia dengan satu atau lebih Tuhan. Beberapa bahasa mengaitkan religion dengan kata relegere, to gather together (berkumpul bersama), atau juga dikaitkan dengan kata religare, yang artinya mengikat kembali (to bind back) atau mengikatkan (to fasten).

Secara semantik kata kepercayaan memiliki beberapa arti, yakni: pertama, iman kepada agama. Kedua, anggapan atau keyakinan bahwa benar sungguh ada. Ketiga, dianggap benar dan jujur. Keempat, setuju kepada kebijaksanaan.

Di Indonesia, kelompok yang merujuk pada sebutan penghayat kepercayaan, setidaknya mengandung empat elemen:

7 The World University Encyclopedia, Vol II, Washington, D.C. Publishers Company, Inc, h. 4250

8 Kamil Kartapradja, Aliran Kebatinan dan Kepercayaan di Indonesia, Yayasan Masagung, Jakarta, 1985, h. 1. a. Kelompok penghayat kepercayaan yang tergolong kepercayaan/agamaagama lokal (suku), seperti kepercayaan Suku Dayak (Kaharingan, Manyaan), suku Batak (Parmalim, si Raja Batak, Namulajadinabolon), Suku Badui, Sunda Wiwitan, Buhun (Jawa Barat), Suku Anak Dalam/Kubu, Suku Wana (Sulawesi Tengah), Tonaas Walian (Minahasa, Sulawesi Utara), Tolottang (Sulawesi Selatan), Wetu Telu (Lombok), Naurus (Pulau Seram, Maluku) dan berbagai kepercayaan di Papua.

b. Kelompok penghayat kepercayaan kepada Tuhan Yang Maha Esa. Masuk dalam kategori ini adalah penganut kebatinan Kejawen pada umumnya yang berpusat di Jawa antara lain Paguyuban Ngesti Tunggal (Pangestu), Sumarah, Susila Budi Dharma (Subud), Perjalanan, Sapta Dharma, Tri Tunggal dan Manunggal, Persatuan Eklasing Budi Murko, Sumarah Purbo, Paguyuban Hardo Pusoro, Ngesti Tunggal, Mardi Santosaning Budi (MSB), Budi Luhur dan lain sebagainya.

c. Kelompok penghayat kepercayaan yang berindikasikan keagamaan meliputi sekte keagamaan, aliran keagamaan, pengelompokan jemaah keagamaan seperti Ahmadiyah, Buda Jawi Wisnu, Children of God, Yehova, Hari Krisna dan lainnya.

d. Kelompok penghayat kepercayaan mistik atau klenik seperti pedukunan, paranormal, peramalan, pengobatan, santet, tenung, sihir dan metafisika9.

Dari aspek kepercayaan, dapat dimengerti kalau suku bangsa Indonesia mula-mula adalah menganut paham animisme. Animisme mempercayai bahwa setiap benda di bumi ini, (seperti kawasan tertentu, goa, pokok atau batu besar), mempunyaijiwayang harus dihormatiagar semangat tersebut tidak mengganggu manusia, malah membantu mereka dari semangat dan roh jahat dan juga dalam kehidupan keseharian mereka ${ }^{10}$.

9 IGM Nurdjana, Hukum dan Aliran Kepercayaan Menyimpang di Indonesia, Pustaka Pelajar, Jogjakarta, 2009, h. 53.

10 Koentjaraningrat, Kebudayaan Jawa, Balai Pustaka, Jakarta, 1994, h. 15-16. 
Dalam konteks kepercayaan, pada masa pra Hindu-Buddha, mereka adalah masyarakat yang sangat menghargai para leluhurnya. Kepercayaan yang muncul biasanya berbentuk keyakinan terhadap adanya jiwa, mirip seperti yang diungkapkan Edward Burnett Tylor tentang asal muasal agama ${ }^{11}$. Bagi Tylor, sebagaimana dikutip Walter $\mathrm{H}$. Capps, definisi minimal tentang agama tidak lain adalah percaya pada spiritual being $^{12}$. Mereka yang menganut aliran ini adalah penduduk mula-mula bangsa Indonesia.

Di dalam sejarahnya, penghayat kepercayaan hidup aman dan nyaman dalam menjalankan kepercayaan yang diyakini dan dianut di Indonesia. Semua itu kemudian menjadi cerita kelabu ketika meletus G $30 \mathrm{~S}$ PKI. Selepas peristiwa 30 September 1965, eksistensi penghayat kepercayaan/kebatinan kerap disandingkan dengan peristiwa tersebut. Tim "Pakem" ditugaskan melakukan pengawasan terhadap para penghayat kepercayaan/ kebatinan. Akibat stigmatisasi dan hubungannya dengan tragedi 1965, maka terjadi eksodus besarbesaran kepindahan penghayat kepercayaan/ kebatinan ke agama-agama"resmi" lainnya ${ }^{13}$.

Kajian mendalam tentang hal ini mengemuka dalam debat yuridis-formal mengenai penghayat kepercayaan dalam tafsir terhadap bunyi Pasal 29 ayat 2 yang menyebut "agama dan kepercayaannya" itu. Kelompok kepercayaan seperti Wongsonagoro memahami kepercayaan dalam kalimat tersebut merujuk pada apa yang disebut sebagai "aliran kepercayaan". Tetapi, ada juga yang memahami kalau kata "kepercayaan" itu maksudnya adalah kepercayaan menurut agamanya ${ }^{14}$, sehingga penghayat kepercayaan di luar "agama resmi" bukan tergolong agama, tetapi budaya.

Problematika itu terus berlanjut. Hampir semua kebijakan tentang penghayat kepercayaan menjadikan Undang-Undang Nomor 1/PNPS/1965 sebagai referensi legalnya. Padahal, undang-undang tersebut secara terang-

11 Walter H. Capps, Religious Studies: The Making of a Discipline, Fortress Press, Minneapolis, 1995, h. 78-83.

12 Ibid., h. 81.

13 Niels Mulder, Kebatinan dan Hidup Sehari-hari Orang Jawa: Kelangsungan dan Perubahan Kulturil, Gramedia, Jakarta, 1984, h. 7.

14 Ibid., h. 54. benderang menjadikan penghayat kebatinan/ kepercayaan sebagai "penoda agama". Mereka bahkan tidak mendapatkan jaminan atas kebebasan berkeyakinan dan menjalankan ibadah menurut keyakinannya. Penghayat kepercayaan menjadi masyarakat agama kelas tiga, dibawah penganut "agama resmi".

Kebijakan politik pemilahan dan pengakuan seperti yang ada dalam Undang-Undang Nomor 1/PNPS/1965, tidak ayal berakibat fatal bagi kelompok-kelompok kepercayaan lokal yang dianut oleh berbagai etnis atau sub-etnis di Indonesia ${ }^{15}$. Apalagi kolom "agama" merupakan kewajiban yang harus diisi mulai sejak Kartu Keluarga, KTP, sampai akta-akta sipil lain yang penting. Termasuk dalam Undang-Undang Nomor 23 Tahun 2006 tentang Administrasi Kependudukan yang disahkan tanggal 8 Desember 2006 yang notabene merupakan era reformasi namun ternyata masih mewajibkannya. Undang-undang inimenarikkarena untukpertama kalinya dalam dokumen resmi Negara dipakai istilah "agama yang belum diakui negara" untuk merujuk pada kelompok-kelompok kepercayaan di luar enam agama yang telah diakui. Padahal kelompok-kelompok ini sangat banyak dan tersebar di seluruh pelosok nusantara. Mereka mencakup bukan hanya sebagai kepercayaan lokal, tetapi kelompok "agama berbasiskan etnis" seperti Sikh, yang dalam dunia internasional diakui sebagai agama ${ }^{16}$.

Pada tataran praktek, biasanya kolom agama di Kartu Tanda Penduduk kelompok kepercayaan harus dikosongkan atau ditandai dengan "-"17. Ini, sudah tentu menimbulkan kerawanan tersendiri, karena mereka takut dituduh "atheis" yang tidak punya tempat di negara ini. Dengan mencantumkan kolom agama dalam KTP, Undang-Undang Administrasi Kependudukan kemudian membatasi penghayat kepercayaan karena tidak sama dengan agama. Hal ini terlihat dalam Pasal 64 ayat 2 yang berbunyi bahwa "Keterangan tentang agama sebagaimana dimaksud pada ayat (1) bagi penduduk yang agamanya belum diakui sebagai

15 Laporan Alternatif Pelaksanaan Konvensi Segala Bentuk Diskriminasi Rasial (ICERD) di Indonesia "Menguak Tabir Diskriminasi Rasial dan Impunity di Indonesia”, paragraf 137.

16 Ibid.

17 Ibid., paragraf 138 
agama berdasarkan ketentuan Peraturan Perundang-undangan atau bagi penghayat kepercayaan tidak diisi, tetapi tetap dilayani dan dicatat dalam data kependudukan". Dengan demikian, Negara telah memberikan ruang bagi para penghayat kepercayaan untuk meyakini dan memeluk kepercayaannya dan dicatatkan dalam data kependudukan sebagai bentuk perwujudan dari pemenuhan hak-hak sipilnya.

\section{Penghormatan HAM bagi Penghayat Kepercayaan: Kasus Kota Bandung}

Penghayat kepercayaan pada umumnya terbagi menjadi dua: penghayat murni dan penghayat yang beragama. Tugas pembinaan organisasi penghayat telah menjadi tugas dari Dinas Kebudayaan dan Pariwisata Provinsi Jawa Barat. Pelaksanaannya sudah berjalan dengan menyelenggarakan sarasehan secara rutin dua kali dalam satu tahun. Sarasehan ini bertujuan menghimpun aspirasi kelompok penghayat. Dari kegiatan sarasehan ini dapat muncul beragam pertanyaan atau permasalahan yang terungkap seperti permasalahan pendidikan kepenghayatan terhadap Tuhan YME bagi anak-anak penghayat. Para penghayat kepercayaan masih merasa takut untuk menyatakan dirinya sebagai penghayat, karena sebagian masyarakat masih belum dapat menerima keberadaan mereka. Banyak organisasi penghayat kepercayaan yang belum mendaftarkan ke pemerintah daerah. ${ }^{18}$

Harapan dari penghayat kepercayaan agar kedepan terdapat pendidikan kepenghayatan bagi anak-anak mereka yang dapat memberikan pemahaman atas nilai-nilai luhur guna ketahanan nasional. Hal ini penting bagi penghayat kerpercayaan karena nilai-nilai luhur yang agung akan tercipta pengembangan sikap kritis bagi generasi muda dalam pembangunan bangsa.

Berdasarkan database Sistem Informasi Administrasi Kependudukan (SIAK) jumlah penghayat kepercayaan di Provinsi Jawa Barat pada tahun 2014 berjumlah 7.839 orang yang ditandai dengan KTP (-). Provinsi Jawa Barat tidak memiliki secara spesifik aturan, baik itu peraturan daerah maupun surat keputusan gubernur tentang pelaksanaan pencatatan kependudukan dan catatan sipil mengenai

18 Hasil Wawancara dengan Dra. Eha(Dinas Kebudayaan dan Pariwisata Provinsi Jawa Barat) pada tanggal 12 November 2015. penghayat kepercayaan ini. Khusus yang terdapat di Kota Bandung, jumlah penghayat kepercayaan sebanyak 104 orang. Hal ini dapat diketahui dari identitas diri (KTP) mereka yang sudah (-) pada kolom agama. Namun jumlah penghayat tersebut tentunya masih lebih banyak lagi. Penghayat yang belum memiliki KTP (-) diyakini masih banyak karena para penghayat tersebut belum berani menyatakan dirinya sebagai penghayat kepercayaan terhadap Tuhan Yang Maha Esa.

Selama ini, di Kota Bandung baru terdapat tiga pasangan yang telah tercatat di Dinas Kependudukan dan Pencatatan Sipil Kota Bandung, dimana pasangan tersebut berasal dari organisasi perjalanan dan telah menikah pada tanggal 28 Mei 2013. Organisasi Perjalanan tersebut telah memiliki 4 orang Pemuka Penghayat yang dapat menikahkan pasangan penghayat sesuai dengan wilayah kerjanya. ${ }^{19}$

DiKotaBandung, setidaknyaada7organisasi penghayat kepercayaan yang terdaftar secara resmi, hanya 2 organisasi yang aktif. Kelima organisasi lainnya tidak aktif karena organisasi tersebut tidak secara rutin melaporkan kegiatan dan anggotanya. Dua organisasi yang aktifadalah organisasi perjalanan dan budi daya. Organisasi kebatinan "Perjalanan" berpusat di Jakarta, namun warganya banyak tersebar di Jawa Barat. Wangsit gaib yang diterima oleh Bapak Mei Kartawinata pada tanggal 17 September 1927 yang diberi nama Dasa Wasita dan menjadi pokok ajaran kebatinan "Perjalanan".

Nama 'Perjalanan' yang digunakan oleh Mei Kartawinata memang mengandung makna filosofis. Hal ini berdasarkan pada pengamatan beliau terhadap 'perjalanan' air sungai Cileuleuy yang mengalir menuju hilir (lautan). Dalam perjalanan tersebut, aliran air itu telah banyak mendatangkan manfaat bagi kehidupan para penghuni alam seperti hewan, tumbuhan dan manusia. Esensi inilah yang ingin diadopsi oleh Mei Kartawinata dalam mengembangkan ajarannya, bahwa kita sebagai manusia haruslah memberikan manfaat bagi alam sekitar kita selama 'perjalanan' manusia 'mengaliri' dinamika kehidupan.

19 Hasil Wawancara dengan Sugiharto (Kepala Bidang Pencatatan, Dinas Kependudukan dan Pencatatan Sipil Kota Bandung) pada tanggal 11 November 2015. 
Dalam buku Teologi Kebatinan Sunda karya peneliti UIN Sunan Gunung Djati, Abdul Rozak, disebutkan bahwa tokoh yang dikenal sebagai spiritualis ini lahir di Bandung pada tanggal 1 Mei 1898. Konon beliau masih keturunan kerabat kerajaan Majapahit (dari garis ayah) dan keluarga Prabu Siliwangi dari Pajajaran (garis ibu). Kondisi masyarakat Sunda dan nusantara secara umum yang terkurung dalam alam penjajahan Eropa ketika itu menimbulkan keprihatinan yang mendalam dalam diri Mei Kartawinata. Keprihatinan itulah yang memicu keinginan beliau untuk terjun ke dunia pergerakan nasional demi mencapai kemerdekaan.

Selain berkecimpung dalam pergerakan politik, seperti yang telah dibahas sebelumnya, Kartawinata juga mengembangkan konsepsi spiritual yang berbasis ajaran Sunda Wiwitan, yang ia namakan aliran Perjalanan. Aliran ini berintikan pada tiga hal, yakni spiritualitas individu berdasarkan ketuhanan, kemanusiaan berbasiskan persamaan, serta kebangsaan berlandaskan karakter dan nation building. Sebagai pedoman bagi para pengikutnya, Kartawinata menulis beberapa buku yang berisi hasil pemikirannya mengenai hakekat kehidupan manusia di dunia. Salah satu buku yang terpenting adalah Budi Daya. Buku ini seringkali dianggap sebagai kitab suci bagi pengikut aliran Perjalanan oleh banyak pihak, meskipun para penganut ajaran Kartawinata sendiri tidak menganggapnya demikian.

Dalam buku Budi Daya, disebutkan makna dari masing-masing sila dalam Pancasila. Sila KeTuhanan Yang Maha Esa diartikan sebagai "daya kaula", sila Kemanusiaan bermakna "badan kaula", sila Kebangsaan maknanya "bakat kaula", sila Kedaulatan Rakyat berarti "darah kaula", serta sila Keadilan Sosial memiliki makna "kacukupan kaula". Jadi dalam arti lain, peran Pancasila dalam kehidupan berbangsa adalah sebagai pemberi kekuatan dan energi bagi rakyat dalam mencapai kesejahteraan bersama seluruh rakyat (kacukupan kaula).

Bila ditelaah, ajaran Kartawinata memang sangat sosialistis. Dalam ajaran tersebut dianjurkan agar manusia menempuh cara hidup sosialistis yang tidak individualis. Kartawinata juga mengintrodusir bentuk masyarakat sosialis yang setiap anggota masyarakatnya harus dapat menyatukan kepentingan dirinya sebagai individu dalam kepentingan masyarakat secara luas. Di sisi lain, kepentingan dan potensi individu akan dilindungi dan dikembangkan oleh masyarakat. Inilah yang menjadi artikulasi dari makna Pancasila dalam kehidupan berbangsa, ketika setiap insan menjadi penggerak sistem/ bangunan kemasyarakatan secara aktif dan kreatif bagaikan darah yang menjadi penggerak atau pemberi daya bagi manusia secara jasmaniah.

Karakter sosialis dalam ajaran Kartawinata juga terlihat dalam Dasa Wasita atau sepuluh wangsit yang menjadi sumber ajaran ini. Pada wangsit kesepuluh ditegaskan bahwa seorang insan harus bergerak untuk kepentingan bersama, dengan cara membantu mereka yang kesulitan agar berkurang penderitaannya. Hal ini perlu dilakukan agar kelak tercapai masyarakat humanis yang merdeka dan gandrung kebenaran. Di masa kini, komunitas pengikutaliran Perjalanan yang berbasis di daerah Ciparay Bandung masih tetap teguh menganut ajaran Mei Kartawinata. ${ }^{20}$

Organisasi Budi Daya merupakan salah satu organisasi yang aktif di Kota Bandung. Organisasi ini sebagian besar anggotanya adalah penghayat murni. Masih terjadi diskriminasi yang dialami oleh para penghayat kepercayaan, bukan dalam hal kependudukan dan catatan sipil, melainkan pada pemakaman. Orang tua dari bapak Engkus meninggal pada tahun 2008 dan terjadi penolakan dari warga sekitar ketika ingin dimakamkan. Pihak keluarga sangat menyesalkan karena tanah tersebut merupakan tanah yang diwakafkan oleh orang tuanya untuk keperluan pemakaman umum. ${ }^{21}$

Penolakan pemakaman tidak boleh terjadi di bumi Indonesia, hal ini disebabkan karena ada aturan yang mengharuskan pemerintah dalam hal ini pemerintah daerah untuk menyediakan lahan bagi warga negaranya yang meninggal dunia. Jika ada pihak atau masyarakat yang menolak maka pemerintah daerah berkewajiban memberikan pemahaman kepada masyarakat akan hak-hak dari penghayat kepercayaan.

Dalam pemenuhan hak-hak sipil bagi penghayat kepercayaan, negara telah

20 http://www.berdikarionline.com/aliran-perjalananspiritualitas-kebangsaan-dari-tatar-sunda

21 Hasil Wawancara dengan Engkus Ruswana (Ketua Umum organisasi Budi Daya) pada tanggal 11 November 2015. 
mempunyai Undang-Undang Nomor 23 Tahun 2006 tentang Administrasi Kependudukan, yang dipandang sebagai langkah terobosan untuk mengatasi masalah diskriminasi di Indonesia. Undang-undang ini menawarkan paradigma baru dalam sistem administrasi kependudukan dimana sistem tersebut dimaksudkan bisa menjamin pemenuhan hak-hak administratif, seperti pelayanan publik serta perlindungan yang berkenaan dengan dokumen kependudukan, tanpa adanya perlakuan yang diskriminatif.

Walaupun dalam Pasal 64 ayat 2 UndangUndangNomor23Tahun2006tentangAdministrasi Kependudukan yang kemudian diubah menjadi Undang-Undang Nomor 24 Tahun 2013 tentang Perubahan atas Undang-Undang Nomor 23 Tahun 2006 tentang Administrasi Kependudukan membatasi penghayat kepercayaan tidak sama dengan agama, namun pemenuhan hak-hak sipil penghayat kepercayaan tetap dilayani dan dicatat dalam data kependudukan dan catatan sipil.

Jika dianalisis lebih lanjut terkait dengan penolakan pemakaman bagi penghayat kepercayaan, dalam Pasal 7 ayat (1) Peraturan Daerah Kota Bandung Nomor 19 Tahun 2011 tentang Ketentuan Pelayanan Pemakaman Umum dan Pengabuan Mayat, Dan Retribusi Pelayanan Pemakaman dan Pengabuan Mayat yang menyebutkan "Dalam upaya meningkatkan efektivitas dan efisiensi lahan TPU, maka Pemerintah Daerah menyediakan TPU Terpadu yang diperuntukan bagi semua pemeluk agama sesuai peraturan perundang-undangan". Peraturan daerah ini tidak menyebutkan agama dan/atau kepercayaan sebagai batasan atau ruang lingkup dari pemeluk agama. Didalam konsideran peraturan daerah ini juga tidak mengingat kepada Peraturan Bersama Menteri Dalam Negeri dan Menteri Kebudayaan dan Pariwisata Nomor 43 dan 41 Tahun 2009 tentang Pedoman Pelayanan kepada Penghayat Kepercayaan Terhadap Tuhan YME. Hal ini sangat memungkinkan tidak terakomodirnya hak-hak sipil dari penghayat kepercayaan dalam hal pemakaman.

\section{PENUTUP}

\section{Kesimpulan}

Di Indonesia terdapat pemilahan antara 6 agama resmi dengan kepercayaan, namun dalam hal pemenuhan hak-hak sipil bagi penghayat kepercayaan tetap dilayani dan dicatat dalam data kependudukan dan catatan sipil dengan diatur oleh berbagai peraturan perundang-undangan. Pada tataran implementasi (khususnya Kota Bandung), para penghayat kepercayaan tidak mengalami kendala dalam memperoleh layanan kependudukan dan catatan sipil, namun masih terdapat penolakan masyarakat umum terhadap pemakaman bagi para penghayat kepercayaan di tempat pemakaman umum.

Penolakan pemakaman bagi penghayat kepercayaan dari masyarakat umum diakibatkan oleh kurangnya pemahaman masyarakat terhadap keberadaan penghayat kepercayaan. Di sisi lain penolakan tersebut dimungkinkan oleh peraturan daerah yang belum mengakomodir nilai-nilai hak asasi manusia, hal ini dapat dilihat pada isi konsideran Peraturan Daerah Kota Bandung Nomor 19 Tahun 2011 tentang Ketentuan Pelayanan Pemakaman Umum dan Pengabuan Mayat, Dan Retribusi Pelayanan Pemakaman dan Pengabuan Mayat.

\section{Saran}

Berdasarkan kesimpulan, maka saran yang dapat disampaikan adalah Pemerintah Daerah Kota Bandung diharapkan dapat merevisi peraturan daerah yang belum mengakomodasi nilai-nilai HAM/kepentingan penghayat kepercayaan. Pemerintah Daerah Kota Bandung, diharapkan dapat memberikan pemahaman melalui diseminasi kepada masyarakat tentang keberadaan penghayat kepercayaan yang dilindungi oleh peraturan perundang-undangan. Pemerintah Daerah Kota Bandung perlu mengembangkan program dan kegiatan tentang kepercayaan terhadap Tuhan Yang Maha Esa melalui media cetak dan media elektronik. 


\section{DAFTAR PUSTAKA}

IGM Nurdjana, Hukum dan Aliran Kepercayaan Menyimpang di Indonesia, Pustaka Pelajar, Jogjakarta, 2009.

Kamil Kartapradja, Aliran Kebatinan dan Kepercayaan di Indonesia, Yayasan Masagung, Jakarta, 1985.

Koentjaraningrat, Kebudayaan Jawa, Balai Pustaka, Jakarta, 1994.

Niels Mulder, Kebatinan dan Hidup Sehari-hari Orang Jawa: Kelangsungan dan Perubahan Kulturil, Gramedia, Jakarta, 1984.

RachelHodgkin and PeterNewell, Implementation Handbook for the Convention on the Rights of the Child, UNICEF, New York, 1998.

Siti Aminah, Diskriminasi Pendidikan Agama di Perguruan Tinggi Umum, Mitra Hukum, ILRC, Jakarta, 2010.

The World University Encyclopedia, Vol II, Washington, D.C. Publishers Company, Inc.

Walter H. Capps, Religious Studies: The Making of a Discipline, Fortress Press, Minneapolis, 1995.

\section{Makalah}

Laporan Alternatif Pelaksanaan Konvensi Segala Bentuk Diskriminasi Rasial (ICERD) di Indonesia "Menguak Tabir Diskriminasi Rasial dan Impunity di Indonesia", paragraf 137.

Mahfud MD, Kebebasan Beragama Dalam Perspektif Konstitusi, Makalah yang disampaikan dalam Konferensi Tokoh Agama ICRP: Meneguhkan Kebebasan Beragama di Indonesia, Menuntut Komitmen Presiden dan Wakil Presiden Terpilih, yang diselenggarakan oleh Indonesian Conference on Religion and Peace (ICRP) pada Senin, 5 Oktober 2009 di Ruang Vanda II Wisma Serbaguna, Jakarta. hIm 1.

The Wahid Institute "Laporan Akhir Tahun Kebebasan Beragama/Berkeyakinan Dan Intoleransi 2014.

\section{Peraturan Perundang-Undangan}

Undang-Undang Dasar Negara Republik Indonesia Tahun 1945.

Undang-Undang Nomor 1/PNPS/1965 tentang Pencegahan Penyalahgunaan dan/atau Penodaan Agama.

Undang-Undang Nomor 23 Tahun 2006 tentang Administrasi Kependudukan.

Undang-Undang Nomor 24 Tahun 2013 tentang Perubahan Atas Undang-Undang Nomor 23 Tahun 2006 tentang Administrasi dan Kependudukan.

Peraturan Pemerintah Nomor 37 Tahun 2007 tentang Pelaksanaan UU No. 23 Tahun 2006.

Peraturan Bersama Menteri Dalam Negeri dan Menteri Kebudayaan dan Pariwisata Nomor 43 dan 41 Tahun 2009 tentang Pedoman Pelayanan kepada Penghayat Kepercayaan Terhadap Tuhan YME.

Peraturan Daerah Kota Bandung Nomor 19 Tahun 2011 tentang Ketentuan Pelayanan Pemakaman Umum dan Pengabuan Mayat, Dan Retribusi Pelayanan Pemakaman dan Pengabuan Mayat 

